\title{
Isotopic composition of precipitation and groundwater onshore of the Rio del Rey Basin, southwest Cameroon: local meteoric lines and recharge
}

\author{
Engome R. Wotany ${ }^{1}$ (D) Mengnjo J. Wirmvem ${ }^{2} \cdot$ Wilson Y. Fantong ${ }^{2} \cdot$ Samuel N. Ayonghe $^{3} \cdot$ Mabel N. Wantim $^{3}$. \\ Takeshi Ohba ${ }^{4}$
}

Received: 18 May 2019 / Accepted: 16 July 2021 / Published online: 24 July 2021

(c) The Author(s) 2021

\begin{abstract}
The link between rainfall and groundwater recharge in the Rio del Rey Basin, which is of socio-economic importance to Cameroon, is poorly understood. Accordingly, the stable isotopes in monthly rainfall from January to December 2012 (in Lobe and Mundemba) and 52 surface water and groundwater samples were investigated. High values of $\delta^{18} \mathrm{O}$ and $\delta \mathrm{D}$ were recorded in the dry period (February to March), and the least values of $\delta^{18} \mathrm{O}$ and $\delta \mathrm{D}$ were observed in the wet period (September). This indicates that different condensation processes primarily influenced stable isotopes in rainfall as a function of the difference in moisture sources. The relationship between $\delta \mathrm{D}$ and $\delta^{18} \mathrm{O}$ defined the Lobe meteoric water line as $\delta \mathrm{D}=7.97$ $\delta^{18} \mathrm{O}+12.48$ and Mundemba water line as $\delta \mathrm{D}=7.75 \delta^{18} \mathrm{O}+10.79$. The similarity of their slopes to the global meteoric line suggests that the isotopic composition of investigated rains was not significantly affected by evaporation during precipitation. The ranges in deuterium-excess of precipitation from 5.8 to $16.56 \%$ o suggest the source of vapour is from the Atlantic Ocean. The groundwater isotope values (ranging from -3.81 to $-2.52 \%$ ofor $\delta^{18} \mathrm{O}$ ) plotted close to and along the GMWL, showing that its isotopic composition is of meteoric origin under rapid recharge conditions. The isotopic similarity between groundwater and June-August rains suggests a significant recharge during this period.
\end{abstract}

Keywords Rainfall $\cdot$ Groundwater $\cdot$ Stable isotopes $\cdot$ Meteoric water line $\cdot$ Recharge $\cdot$ Ndian-Cameroon

\section{Introduction}

The availability of freshwater is necessary for any meaningful socio-economic development. Due to the lack of pipeborne water in the study area (Ndian), $80 \%$ of the population depends on groundwater sources such as hand-dug wells and springs and faced with water shortages during the dry season. Therefore, these communities' resort to poor quality

Engome R. Wotany

wotanyr@gmail.com

1 Department of Geology, Faculty of Science, University of Buea, P.O. Box 63, Buea, Cameroon

2 Institute of Geological and Mining Research, P.O. Box 4110, Yaounde, Cameroon

3 Department of Environmental Science, Faculty of Science, University of Buea, P.O. Box 63, Buea, Cameroon

4 Department of Chemistry, School of Science, Tokai University, Hiratsuka 259-1211, Japan water from streams, rivers and the creeks for household use during such periods (Wotany et al. 2013). The quality of the available water in this area is affected by deterioration from effluents from processing factories owned by CDC and PAMOL that are piped or channelled directly into streams and rivers of the area (Tening et al. 2014). Chemicals from the effluents find themselves in water bodies and hence undesirable burdens to the mangrove ecosystem of the study area. Consequently, the assessment and management of water resource in the area are of importance. In recent years, the isotope techniques have been used in water resource management investigations by studying of isotopic composition of surface and groundwater (Craig 1961; Dansgaard 1964; Fontes 1980; Gonfiantini et al. 1998; Gat 2010; Wu et al. 2012). Based on the socio-economic importance of the Rio del Rey Basin, and the lack of isotopic data, studies of the seasonal variation in stable isotope values are of importance to determine the source and recharge of groundwater in the study area. The oxygen-18 and deuterium isotopes are used as tracers for hydrologic studies because their local 
abundance varies significantly with environmental factors such as the altitude of precipitation, source of moisture, amount of rainfall, and extent of evaporation (Ingraham 1998). They are used as tracers in understanding the movement of air masses and continental moisture, evaporation of water bodies and origin of surface and groundwater (Gibson et al. 2005; Kendall and Coplen 2001; Liu et al. 2004; Wirmvem et al. 2014). The objectives of this study included: (1) define the spatio-temporal variations of isotopic composition in rainfall of the study area; (2) produce local meteoric water lines; (3) deduce the origin and recharge period of groundwater for development and sustainability management of groundwater resource.

The study area is located at the western end of the Gulf of Guinea at latitude $4^{\circ} 30^{\prime}-5^{\circ} 00^{\prime} \mathrm{N}$ and longitude $8^{\circ} 30^{\prime}-9^{\circ} 00^{\prime}$. The hydrological cycle is mainly a function of the precipitation regime of an equatorial climate (Etia 1980), with an alternating long rainy season that begins from April to October and a short dry season that spans from November to March.

The drainage pattern (Fig. 1) is dendritic and dominated by rivers that flow into the Atlantic Ocean. These rivers may partly recharge groundwater through unconsolidated sediments and weathered volcanic and basement rocks in the area. The topography can conveniently be divided into different topographical regions (Fig. 2): the MosongeseliIsangele area with an elevation between 2 and $40 \mathrm{~m}(\mathrm{~m})$ above sea level (a.s.l). It generally consists of long ridges with flat or gently undulating crests. Between the ridges are flat, swampy areas where the water table is at or close to the surface. The Mundemba-Ekwe area elevation increases from $80 \mathrm{~m}$ a.s.l. in the south-west to $555 \mathrm{~m}$ a.s.l. in the south-east along the edge of the rugged Rumpi Hills.

This area is characterized by mangroves of $0-5 \mathrm{~m}$ high (Gabche and Smith 2002). Mangroves occupy approximately $30 \%\left(3500 \mathrm{~km}^{2}\right)$ of Cameroon coastal zone (Gabche and Smith 2002) and proceed inland by evergreen forest, which is subjected to intense destruction for plantation agriculture (oil palm, cocoa, and coffee). Four different associations exist: a lowland evergreen, the swamp forest, the piedmont and submontane forests found at altitudes between 500 and $800 \mathrm{~m}$ (Letouzey 1985; Thomas 1995, 1997). The canopy type here is $10-15 \mathrm{~m}$ high which protects the watershed of the Rumpi Hills. Within the Rio del Rey, apart from the

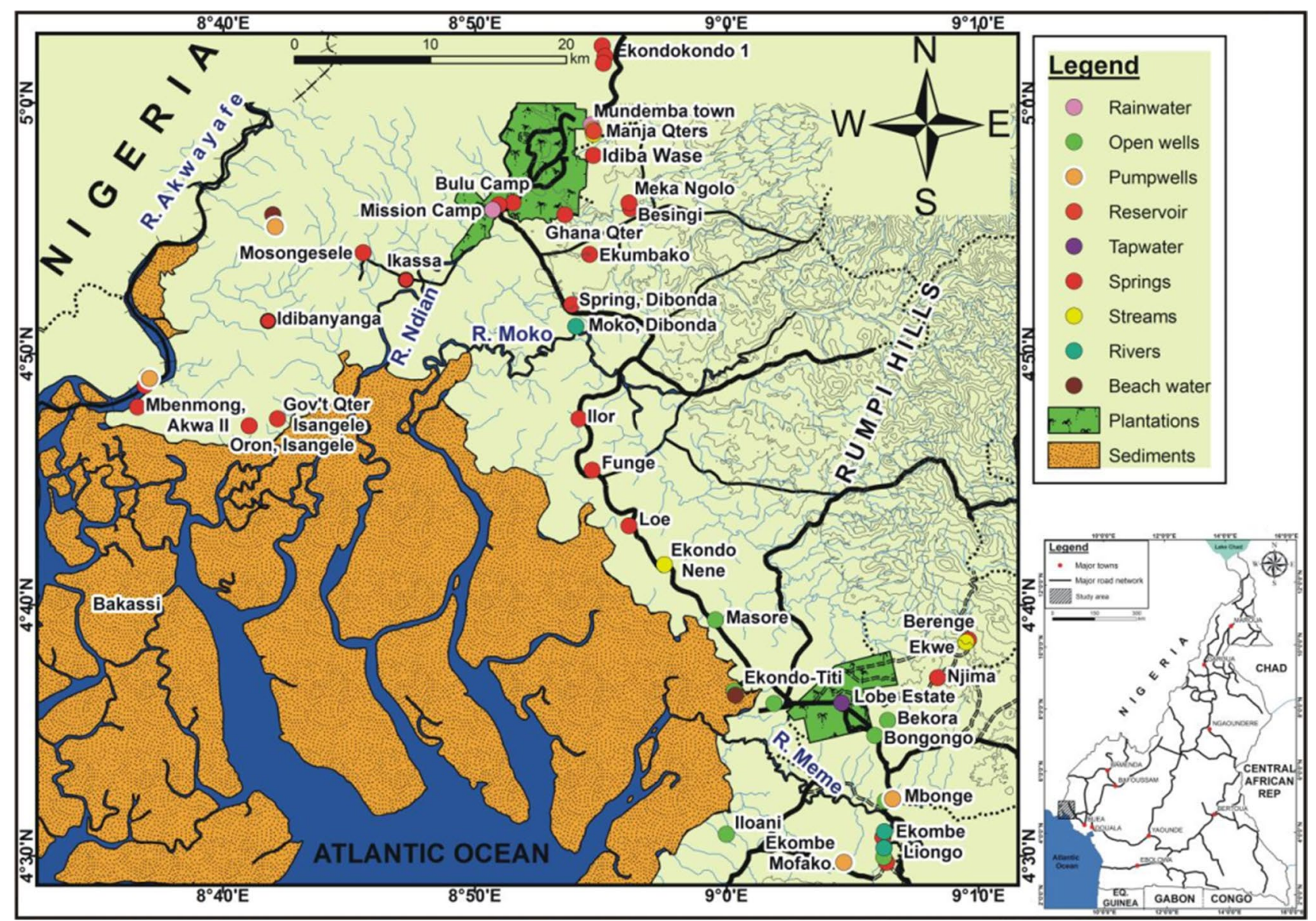

Fig. 1 Map location of sampling sites and drainage pattern of the study area. Inset: Cameroon map showing study area (shaded rectangle) 


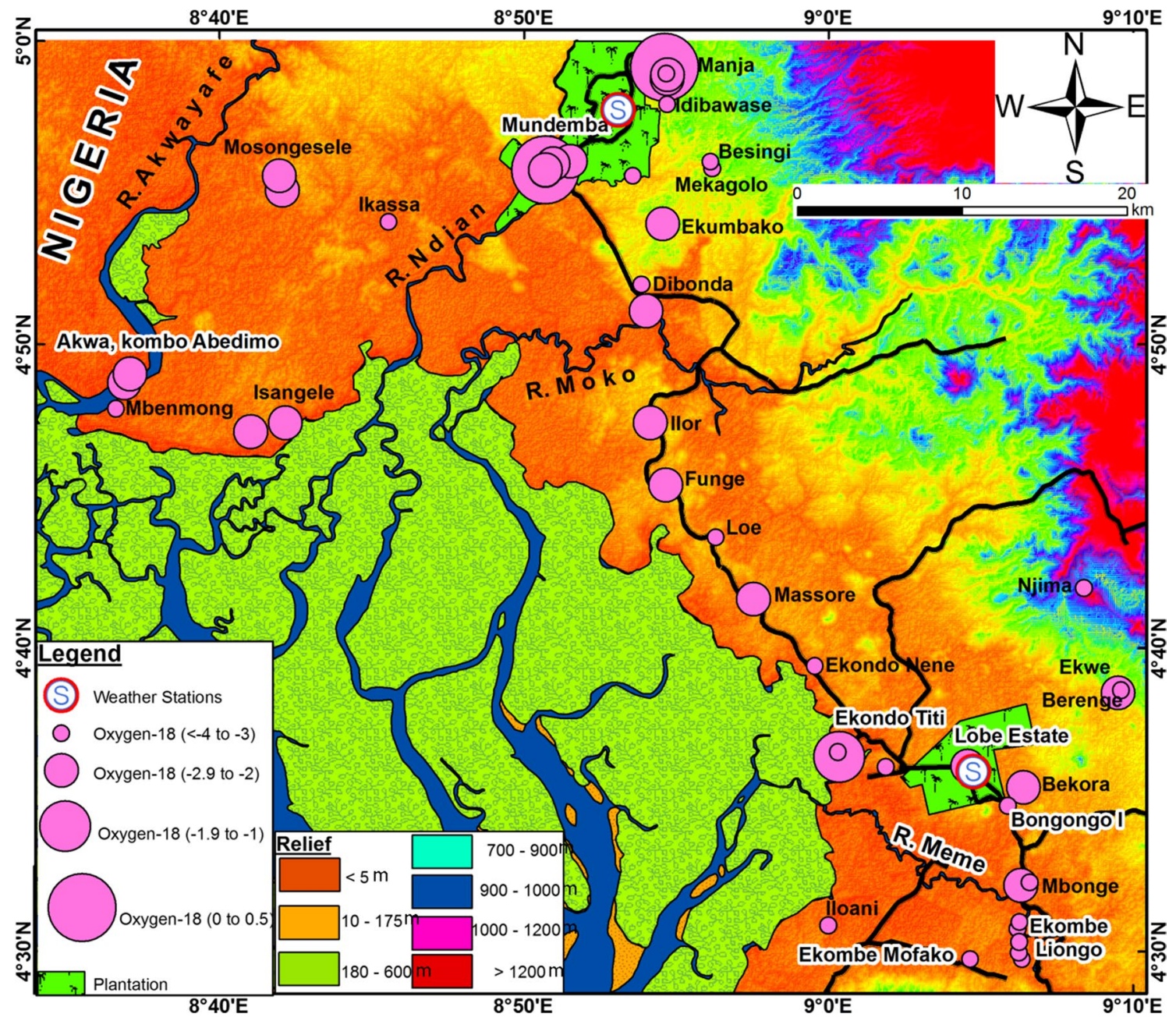

Fig. 2 Map of study area showing relief and spatial distribution of oxygen-18 of ground and surface water sources

traditional cash crops such as cocoa, agro-industrial activities of the area concern essentially oil palm, rubber and banana, which are in the hands of large scale agro-industrial establishments (Tening et al. 2013; Wotany et al. 2014).

The study area is characterized by varied geological settings: metamorphic, volcanic and sedimentary rocks. The variety of rocks includes gneisses, micaschists, and quartzites overlain uncomfortably by limestones, sediments which are essentially clastics consisting of sand, sandstones, conglomerates, limestones, shales, clays, alluvium and basaltic lava flows from the Rumpi Hills (Dumort 1968; Obenesaw et al. 1997; Njoh and Petters 2008; Wotany et al. 2013). Regnoult (1986) also describes the area as made up of limestones, shales, clays of Cretaceous age, and Mio-Pliocene sediments with recent alluvium. Alluvial sand, fractured basement and basaltic materials make up the unconfirmed aquifers. The aquifers of the study area are similar to those of the Oligocene Benin and the Eocene Ogwashi/Asaba aquifers within the Niger Delta Basin, Nigeria. The area has a multi-aquifer system characterized by alternating layers of gravels, sands, silts and clays similar to the aquifers of the Douala basin as described (Mafany et al. 2006; Takem et al. 2010; UNESCO - ISARM 2011; Wotany et al. 2014: Fig. 3).

\section{Materials and methods}

Precipitation samples were collected as described by Goni (2006) for a period of one year (January to December 2012) from two rain gauge stations owned by the Pamol research centres (Mundemba: UTM 54,480; 484,386:32masl and Lobe: 508,790; 508,299:61masl) (Fig. 1). Rain samples collected daily for twelve months were poured into $5 \mathrm{~L}$ sealed plastic containers. The integrated rain samples were poured into $100 \mathrm{~mL}$ polythene bottles tightly capped and stored in a cold environment preceding laboratory analysis. Temperature and relative humidity measurements were also recorded. Fifty-two 


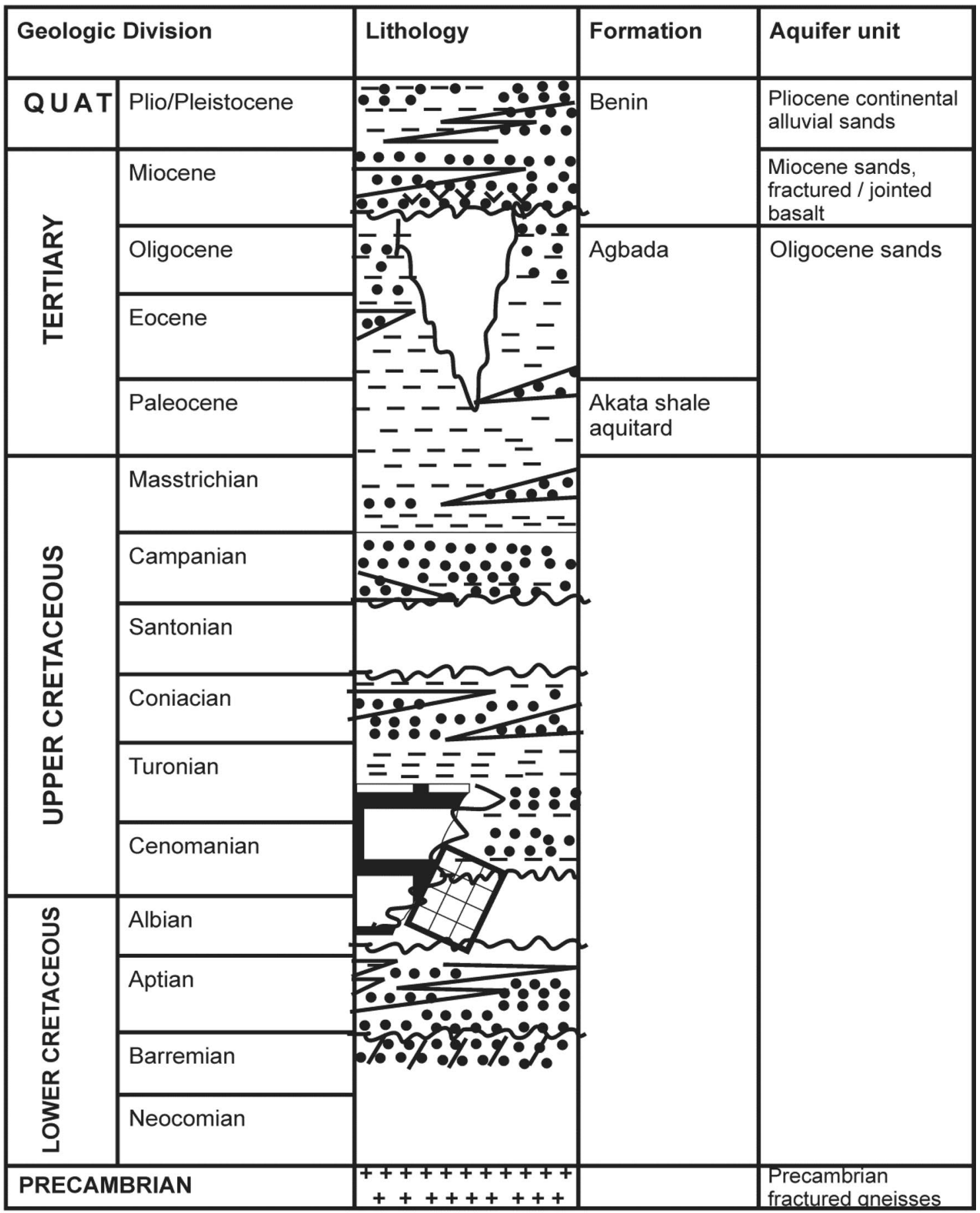

Legend

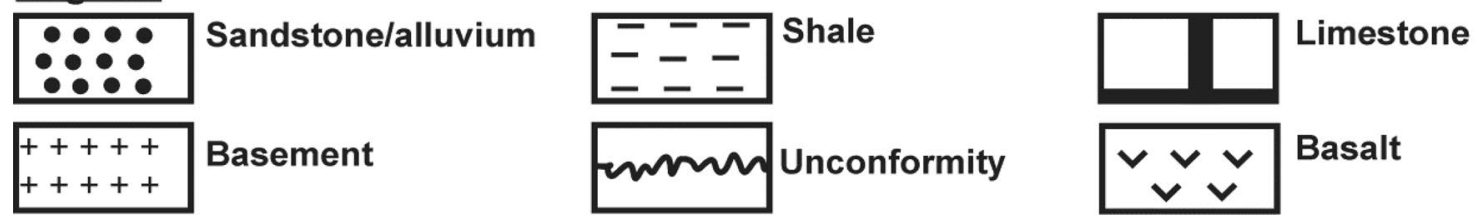

Fig. 3 Hydrostratigraphic column of the Rio del Rey Basin showing the various aquifer units modified from UNESCO - ISARM (2011) 
water samples obtained from ground and surface water were also put in plastic bottles $(100 \mathrm{~mL})$ for oxygen and hydrogen isotope analysis. The deuterium (D) and oxygen-18( $\left({ }^{18} \mathrm{O}\right)$ composition were analyzed using a cavity ring-down spectrometer analyzer (model L2120-i from PICARRO) as described in Wirmvem et al. (2014). Total analytical precisions were $\pm 0.05 \% \circ\left(\delta^{18} \mathrm{O}\right)$ and $\pm 0.12 \%$ 。 $(\delta \mathrm{D})$. The precipitation weighted average values (w.a.v) of $\delta^{18} \mathrm{O}$ and $\delta \mathrm{D}$ for each month and the annual values were computed from Eq. 1(IAEA 1992):

$\delta=\sum_{1}^{n} P_{i} \delta / \sum_{1}^{n} P_{i}$

where $P_{i}$ is rainfall amount, and $\delta_{i}$ is isotopic composition per month. The deuterium-excess ( $d$-excess) parameter was obtained as defined by Dansgaard (1964) as: $d=\delta D-8 \delta^{18} O$

\section{Results and discussions}

The isotopic data for the monthly precipitation are presented in Table 1 . The monthly precipitation values for $\delta^{18} \mathrm{O}$ and $\delta \mathrm{D}$ of the two stations show a temporal variation from -5.26 to $+0.35 \%$ and from -34.4 to $+13.88 \%$, respectively (Table 1).

Monthly weighted average values (w.a.v) of $\delta^{18} \mathrm{O}$ and $\delta \mathrm{D}$ in precipitation ranged from -0.98 to $0.00 \%$ and from -3.59 to $0.59 \%$, in that order. The annual precipitation weighted mean of $\delta^{18} \mathrm{O}$ and $(\delta \mathrm{D})$ varied from -3.36 to $-3.34 \%$ and from -15.07 to $-14.0 \%$, respectively (Table 1). The seasonal variations of $\delta^{18} \mathrm{O}$ and $\delta \mathrm{D}$ showed

Table 1 Isotopic data of monthly rainfall and weather records from Rio del Rey Basin, 2012

\begin{tabular}{|c|c|c|c|c|c|c|c|c|c|c|}
\hline Month & $\delta^{18} \mathrm{O}(\% \circ)$ & $\delta \mathrm{D}(\% \circ)$ & d-excess $(\% o)$ & Rainfall (mm) & w.a.v $\delta^{18} \mathrm{O}$ & w.a.v $\delta \mathrm{D}$ & w.a.v d-excess & Rainy days & $\mathrm{RH}(\%)$ & Temp $\left({ }^{\circ} \mathrm{C}\right)$ \\
\hline \multicolumn{11}{|c|}{ LOBE (UTM 508,790; 508,299 m; alt $60 \mathrm{~m}$; distance from the Atlantic Ocean: $32 \mathrm{~km}$ ) } \\
\hline January & -1.57 & -2.61 & 9.97 & 43 & -0.02 & -0.04 & 0.13 & 3 & 90.2 & 27 \\
\hline February & -0.99 & 2.16 & 10.08 & 147 & -0.05 & 0.10 & 0.46 & 12 & 90 & 27 \\
\hline March & -1.54 & 2.61 & 14.94 & 14 & -0.01 & 0.01 & 0.07 & 3 & 90 & 27 \\
\hline April & -2.26 & -1.53 & 16.56 & 139 & -0.10 & -0.07 & 0.72 & 11 & 90.1 & 27 \\
\hline May & -4.53 & -20.70 & 15.55 & 217 & -0.31 & -1.41 & 1.06 & 17 & 90.1 & 28 \\
\hline June & -3.90 & -16.74 & 14.43 & 327 & -0.40 & -1.71 & 1.48 & 16 & 90.7 & 27 \\
\hline July & -2.94 & -9.79 & 13.73 & 424 & -0.39 & -1.30 & 1.82 & 27 & 90.2 & 27 \\
\hline August & -1.60 & -0.18 & 12.64 & 342 & -0.17 & -0.02 & 1.36 & 29 & 90.3 & 27 \\
\hline September & -5.26 & -34.44 & 7.61 & 770 & -1.27 & -8.32 & 1.84 & 22 & 90 & 27 \\
\hline October & -4.81 & -25.38 & 13.13 & 541 & -0.82 & -4.31 & 2.23 & 24 & 90 & 27 \\
\hline November & -2.14 & -7.01 & 10.12 & 109 & -0.07 & -0.24 & 0.35 & 9 & 90.1 & 27 \\
\hline December & -2.31 & -6.37 & 12.13 & 116 & -0.08 & -0.23 & 0.44 & 6 & 90.1 & 28 \\
\hline Mean & -2.82 & -10.00 & 12.57 & 3188 & -2.82 & -10.00 & 12.57 & 179 & 90 & 27 \\
\hline Annual w.a.v & & & & & -3.7 & -14.0 & 12.7 & & & \\
\hline \multicolumn{11}{|c|}{ MUNDEMBA (UTM 544,804; 484,386 m; alt $30 \mathrm{~m}$; distance from the Atlantic Ocean: $61 \mathrm{~km})$} \\
\hline January & -1.10 & -0.18 & 8.60 & 65 & -0.01 & 0.00 & 0.11 & 5 & N/A & 31 \\
\hline February & 0.02 & 13.01 & 12.86 & 217 & 0.00 & 0.56 & 0.55 & 17 & N/A & 27 \\
\hline March & 0.35 & 13.88 & 11.08 & 214 & 0.01 & 0.59 & 0.47 & 11 & N/A & 29 \\
\hline April & -1.80 & 0.81 & 15.21 & 290 & -0.10 & 0.05 & 0.87 & 16 & N/A & 28 \\
\hline May & -4.30 & -21.68 & 12.72 & 223 & -0.19 & -0.95 & 0.56 & 17 & N/A & 28 \\
\hline June & -3.32 & -11.65 & 14.88 & 650 & -0.43 & -1.49 & 1.91 & 21 & N/A & 27 \\
\hline July & -4.28 & -19.33 & 14.91 & 941 & -0.79 & -3.59 & 2.77 & 30 & N/A & 25 \\
\hline August & -3.48 & -14.49 & 13.35 & 486 & -0.33 & -1.39 & 1.28 & 21 & N/A & 25 \\
\hline September & -4.66 & -31.45 & 5.83 & 1065 & -0.98 & -6.61 & 1.23 & 26 & N/A & 26 \\
\hline October & -4.53 & -24.49 & 11.75 & 570 & -0.51 & -2.75 & 1.32 & 21 & N/A & 27 \\
\hline November & -2.38 & -10.86 & 8.19 & 289 & -0.14 & -0.62 & 0.47 & 19 & N/A & 27 \\
\hline December & -0.34 & 4.74 & 7.44 & 57 & 0.00 & 0.05 & 0.08 & 6 & N/A & 27 \\
\hline Mean & -2.48 & -8.47 & 11.40 & 5067 & -2.48 & -8.47 & 11.40 & 210 & N/A & 27.33 \\
\hline WAV & & & & & -3.36 & -15.07 & 12.16 & & N/A & \\
\hline
\end{tabular}

$N B$; relative humidity $(R H)$, not available (N/A), bolditalics min values, italics max values, weighted average value (w.a.v) 
some distinct fluctuations in the rainy and dry seasons. In the rainy season, the least of $\delta^{18} \mathrm{O}$ and $\delta \mathrm{D}$ were recorded in September and relatively high values in March during the dry season (Fig. 4a, b). The precipitation amount effect generally shows a decrease in the isotope values in wet period with increasing precipitation (Dansgaard 1964) and usually with high values during the dry period with decreasing rainfall (Wirmvem et al. 2014). The isotopic amount effect pattern observed (Fig. 4a, b) suggests that the rainy and dry season rains are connected with the air masses rain formation processes. This suggests the inter tropical convergence zone (ITCZ) influence associated with the easterly winds during the rainy period and the dry season with less frequent rains carried by northerly or westerly winds. An abrupt decrease in $\delta^{18} \mathrm{O}$ in November possible marks the retreat of the ITCZ (Fig. 4a, b).
The least $\delta^{18} \mathrm{O}$ values in September, corresponding with the highest rainfall, correspond with the behaviour of low latitudes rains (Dansgaard 1964; Rozanski et al. 1993). Similar patterns of least values of $\delta^{18} \mathrm{O}$ obtained during the rainy season have been recorded in Cameroon (Njitchoua et al.1999; Wirmvem et al. 2014).

The annual variation in the weighted $\delta^{18} \mathrm{O}$ was observed with similar v-shape patterns in the Ndop plain in the North West Cameroon (Wirmvem et al. 2014) which suggest a moisture source from the Atlantic. (Taupin et al. 2000).

Rain samples from high altitudes are more depleted in isotope content (Lobe (61 m above sea level); $-0.56 \%$ o to $-0.99 \%$ ) than precipitation sampled at low altitude station (Mundemba (32 m); $-0.56 \%$ o to $0.35 \%$ ) Table 1 . The annual weighted average value (w.a.v) for $\delta^{18} \mathrm{O}$ in precipitation in Mundemba $(-3.36 \%$ ), Lobe $(-3.34 \%$ ) compared with Kribi $(-1.5 \%$ ) (Njitchoua et al. 1999) in
Fig. 4 a, b Inverse relationship between monthly rainfall amounts and weighted mean of $\delta^{18} \mathrm{O}$ for a Mundemba and b Lobe
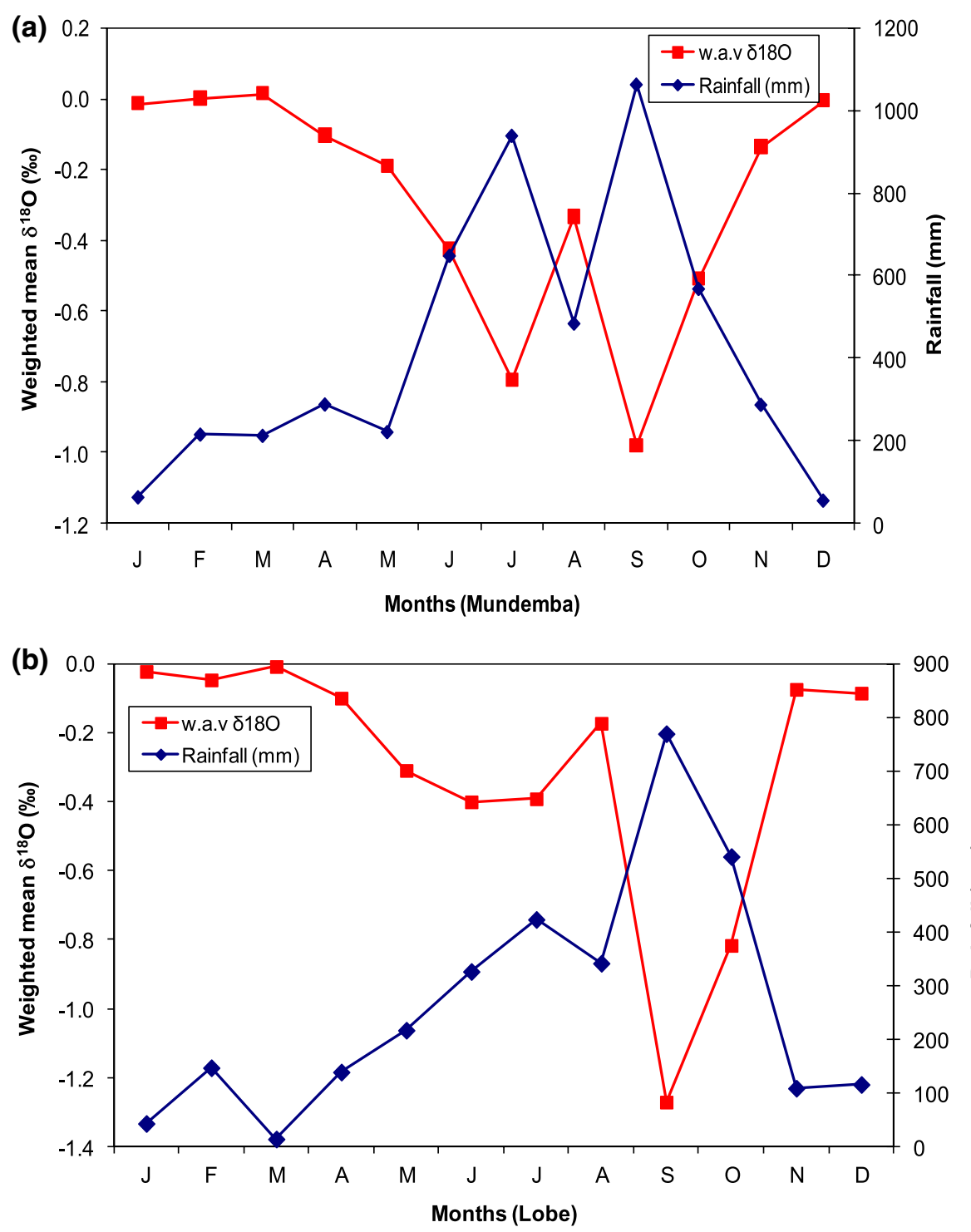
Fig. 5 shows a decrease with increasing latitudinal distance from Kribi $(-1.5 \% / \mathrm{km})$ to Lobe $(-3.34 \%$ : $32 \mathrm{~km})$, and Mundemba $(-3.36 \%: 61 \mathrm{~km})$ inland. Two main trends are defined (Fig. 5): $\delta^{18} \mathrm{O}$ values which decrease from -1.5 to $-3.34 \%$, from 0 to $32 \mathrm{~m}$, defining an inland isotope of $-0.48 \% \circ 10 \mathrm{~km}^{-1}$. This is different from $\delta^{18} \mathrm{O}$ values from Lobe $(-3.34 \%$ ) to Mundemba $(-3.36 \%$ of 32 to $61 \mathrm{~km}$ inland isotopic gradient of $-0.06 \% \circ 10 \mathrm{~km}^{-1}$. This suggests that as Atlantic air mass moves at higher altitudes and latitudes from the Atlantic Ocean, the vapour is produced as rain. This is different from $\delta^{18} \mathrm{O}$ values (32-61 km inland) influenced recycled continental moisture as also observed by Salati et al. (1979), Njitchoua et al. (1999) and Taupin et al. (2000. The relatively small isotopic gradient of $-0.06 \%$ o $10 \mathrm{~km}^{-1}$ indicates a lack of continental effect e from the coast as observed in the Ndop plain (Cameroon) by Wirmvem et al. (2014).

Deuterium excess in precipitation has been a useful tool to trace vapour source and recycling moisture (Gat et al. 1994). Monthly d-excess of precipitation ranged broadly from 5.8\% in September to 16.56\% in April (Table 1).

The d-excess value in precipitation is influenced by the moisture source (Rozanskiet al. 1993). The d-excess value of Atlantic moisture $(10 \%)$ falls between the d-excess ranges of the rain samples (5.8-16.56\%o) indicating the significance of the Atlantic ocean as a vapour source of the study area. Higher d-excess values $(>10 \%$ o $)$ have been observed where moisture recycling through re-evaporation plays a significant role in the water cycle (Gat et al. 1994; Zhou et al. 2007). Seventeen (17) d-excess values were greater than $+10 \%$ o (Fig. 6a, b), which suggests that besides the Atlantic moisture, an additional source of moisture recycling through evaporation of the numerous surface water bodies and/or evapotranspiration on the dense vegetation in the area plays a role in the water cycle.

The local meteoric line (LML) has been commonly used as an indicator of water vapour source (Jouzel et al.

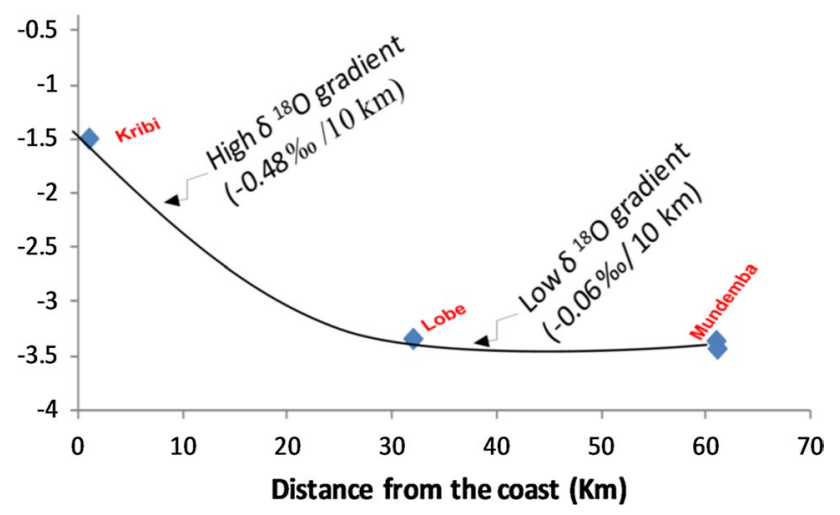

Fig. 5 Distribution of weighted mean $\delta^{18} \mathrm{O}$ in rainfall per distance and altitude from the Atlantic Ocean
1997). By using the precipitation isotope values and the least squares fit method (Fig. 7), the following LML were generated:

Lobe meteoric water line (LMWL) $\delta \mathrm{D}=7.97$ $\delta^{18} \mathrm{O}+12.48\left(r^{2}=0.95, n=12\right)$

Mundemba meteoric water line (MMWL): $\delta \mathrm{D}=7.75$ $\delta^{18} \mathrm{O}+10.79\left(r^{2}=0.95, n=12\right)$

The slopes (7.9 and 7.7) for the local meteoric lines (Fig. 7) are similar and close to 8 of the GMWL $\left(\delta \mathrm{D}=8 \delta^{18} \mathrm{O}+10\right)$ by Craig (1961), which suggest an insignificant modification of the raindrops by evaporation as obtained in other parts of Cameroon (Fontes and Olivry 1977; Njitchoua et al. 1999; Gonfiantini et al. 2001; Fantong 2010; Wirmvem et al. 2014). Quite identical relationships of $\delta^{18} \mathrm{O}-\delta \mathrm{D}$ have been reported for precipitation in parts of Nigeria (Loehnert 1988; Mbonu and Travi 1994). The varied d-intercepts reflect seasonal climatic changes (Gonfiantini et al. 2001; Wirmvem et al. 2014).

The uniform and high mean relative humidity $(90 \%)$ for Lobe (Table 1) suggests its proximity to the coast with a distance of $32 \mathrm{~km}$ and to its equatorial location which makes it to be subjected to intense convective uplift of air/water vapour since the sun's rays reach the surface vertically at an angle of $90^{\circ}$. Considering the total amount of rainfall in the study area (Table 1) from January to May and November to December which is $2,143 \mathrm{~mm}(26 \%)$ of the total rainfall $(8259 \mathrm{~mm})$, and the June to October heavy rains which is $6116 \mathrm{~mm} \mathrm{(74 \% )}$ of the total rainfall, and based on the $\mathrm{d}$-excess and $\delta$-values, one can suggest that $74 \%$ of rainfall comes from the Atlantic Ocean, and 26\% of vapour originates from recycled inland moisture. The former relates to the fact that the inter tropical convergence zone (ITCZ) has moved further inland which brings with it rain bearing moisture that flows across the region. Therefore, the observed seasonal variation in the isotopic composition of precipitation in the study area is probably as a result of (1) moisture from the Atlantic Ocean, (2) rainfall amounts effects (3) recycled moisture given the 32-61 km distance south-west from the Atlantic Ocean (Gulf of Guinea), (4) movement of air masses.

The stable isotope composition of ground and surface water is presented in Table 2 . The groundwater isotope values ranged from -3.81 to $-2.52 \%$ or $\delta^{18} \mathrm{O}$ and -16.63 to $-8.25 \%$ o for $\delta \mathrm{D}$ (Table 3 ). The groundwater isotope values plot close to and along the GMWL (Fig. 8) showing that its isotopic composition is identical to that of rainwater, which indicates the meteoric origin and rapid recharge of groundwater with negligible evaporative effect. The cluster of these isotopes in groundwater between the June to August rain indicates groundwater is mainly recharged during these months of the year (Fig. 8). The shallow unconfined aquifers 
Fig. 6 a, b Inverse relationship between monthly rainfall amounts and d-excess for a Lobe and $\mathbf{b}$ Mundemba
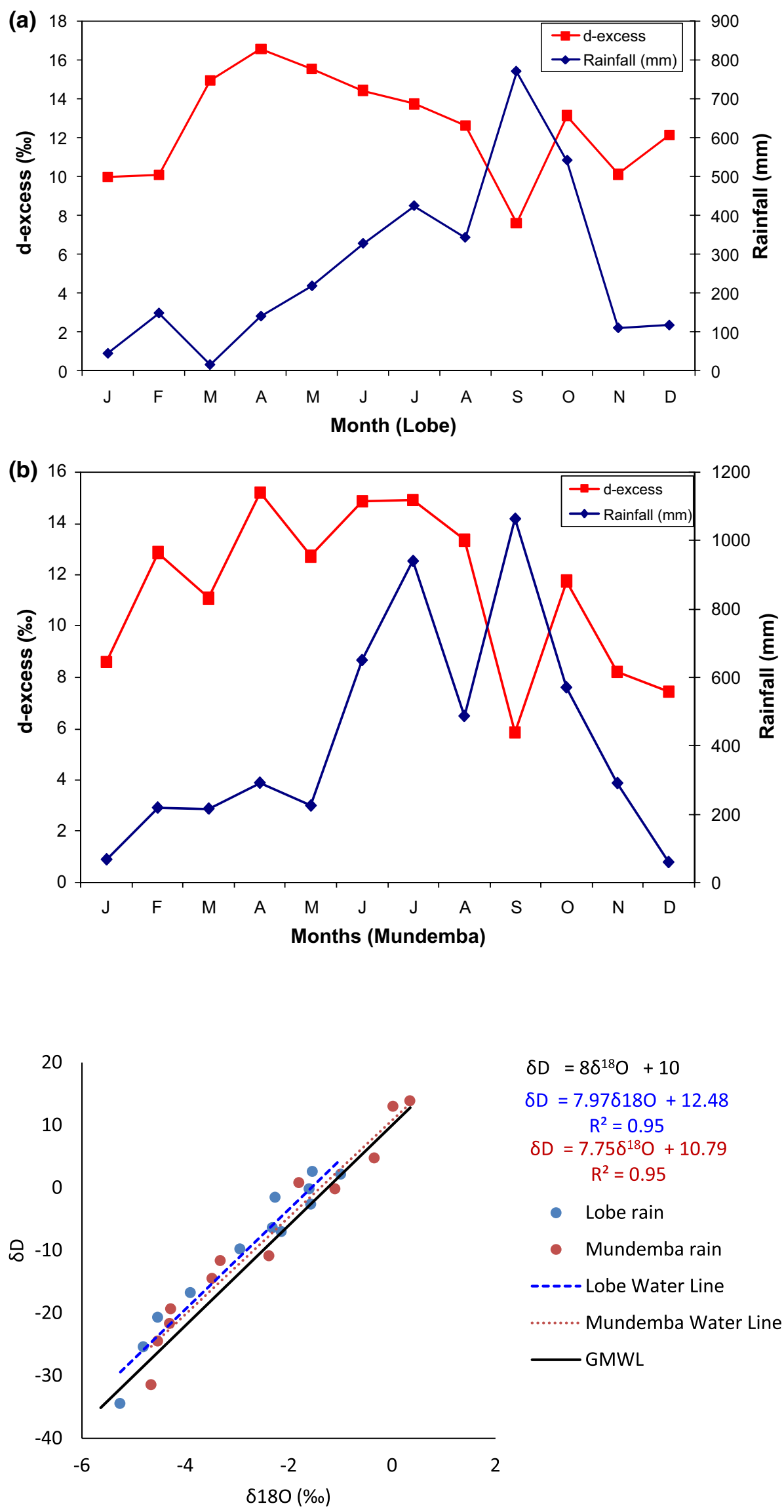

$$
\begin{aligned}
& \delta \mathrm{D}=8 \delta^{18} \mathrm{O}+10 \\
& \delta D=7.97 \delta 180+12.48 \\
& R^{2}=0.95 \\
& \delta \mathrm{D}=7.75 \delta^{18} \mathrm{O}+10.79 \\
& \mathrm{R}^{2}=0.95
\end{aligned}
$$


Table 2 Oxygen and hydrogen isotope data of ground and surface water

\begin{tabular}{|c|c|c|c|c|c|c|c|}
\hline Locality & Water source & Long (m) & Lat (m) & Altitude & $\delta \mathrm{D}(\% \circ)$ & $\delta^{18} \mathrm{O}(\% \circ)$ & d-excess $(\% o)$ \\
\hline Bulu Camp, Mundemba & Spring & 484,310 & 545,361 & 35 & -9.78 & -2.77 & 12.35 \\
\hline Mission Camp, Mundemba & Spring & 483,280 & 545,216 & 30 & -9.77 & -2.79 & 12.58 \\
\hline Ikassa Camp, Mundemba & Spring & 482,836 & 544,838 & 33 & -6.16 & -2.28 & 12.07 \\
\hline Last Camp, Mundemba & Spring & 482,814 & 544,840 & 13 & -9.61 & -2.72 & 12.18 \\
\hline Ekondokondo & Spring & 490,869 & 556,878 & 160 & -8.34 & -2.66 & 12.97 \\
\hline Ekondokondo & Spring & 491,075 & 556,114 & 142 & -10.15 & -2.98 & 13.69 \\
\hline Ekondokondo & Spring & 490,958 & 555,612 & 125 & -9.13 & -2.82 & 13.4 \\
\hline Mekagolo & Spring & 492,947 & 544,933 & 156 & -11.94 & -3.4 & 15.28 \\
\hline Ekumbako & Spring & 489,943 & 541,560 & 123 & -9.92 & -2.97 & 13.81 \\
\hline Dibonda & Spring & 488,633 & 537,873 & 94 & -10.81 & -3.19 & 14.72 \\
\hline Funge & Spring & 490,123 & 525,715 & 20 & -9.53 & -2.94 & 13.95 \\
\hline EkombeLiongo & Spring & 511,552 & 497,985 & 33 & -13.81 & -3 & 10.2 \\
\hline EkombeLiongo & Spring & 511,743 & 496,931 & 44 & -15.45 & -3.59 & 13.24 \\
\hline EkombeLiongo & Spring & 511,476 & 498,765 & 29 & -12.8 & -3.21 & 12.91 \\
\hline IdibaNyanga & Spring & 456,750 & 530,354 & 110 & -12.71 & -3.03 & 11.56 \\
\hline Njima & Spring & 515,488 & 519,485 & 40 & -12.66 & -3.16 & 12.64 \\
\hline Oron, Isangele & Spring & 467,033 & 529,483 & 89 & -10.59 & -2.93 & 12.88 \\
\hline Pamol Camp, Mundemba & Spring & 473,308 & 541,683 & 4 & -12.76 & -3.26 & 13.29 \\
\hline Ilor & Spring & 489,169 & 529,483 & 110 & -10.76 & -2.99 & 13.18 \\
\hline Ghana Quarter, Mundemba & Spring & 488,124 & 544,472 & 105 & -11.38 & -3.06 & 13.11 \\
\hline Loe & Spring & 482,829 & 521,639 & 58 & -12.76 & -3.25 & 13.41 \\
\hline Mbengmong, Akwa II & Spring & 457,273 & 531,923 & 10 & -10.02 & -2.76 & 12.09 \\
\hline Gov't quater, Isangele & Spring & 464,942 & 528,959 & 89 & -10.66 & -2.83 & 11.97 \\
\hline Ekwe & Spring & 517,754 & 513,273 & 555 & -11.51 & -3.36 & 15.34 \\
\hline Idibawase & Spring & 490,215 & 548,830 & 100 & -13.08 & -3.45 & 14.49 \\
\hline Besingi & Spring & 492,829 & 545,344 & 155 & -11.66 & -3.21 & 14.03 \\
\hline Massore & Open well & 499,171 & 514,728 & 32 & -16.99 & -3.8 & 13.4 \\
\hline EkondoTiti & Open well & 500,564 & 509,508 & 9 & -12.38 & -3.25 & 13.59 \\
\hline EkondoTiti & Open well & 503,472 & 508,591 & 52 & -13.46 & -3.35 & 13.38 \\
\hline Big Bongongo I & Open well & 510,885 & 506,248 & 60 & -12.35 & -3.17 & 13 \\
\hline EkombeLiongo & Open well & 511,534 & 497,310 & 33 & -14.63 & -3.27 & 11.51 \\
\hline Mbonge & Open well & 511,653 & 501,421 & 21 & -10.74 & -2.64 & 10.39 \\
\hline Iloani & Open well & 499,976 & 498,981 & 10 & -13.66 & -3.36 & 13.2 \\
\hline Bekora & Open well & 511,828 & 507,347 & 55 & -10.23 & -2.85 & 12.55 \\
\hline Mbonge & Pump well & 512,191 & 501,583 & 26 & -13.5 & -3.31 & 12.94 \\
\hline Akwa, KomboAbedimo & Pump well & 457,622 & 532,446 & 8 & -8.35 & -2.64 & 12.77 \\
\hline Mosongesele & Pump well & 466,859 & 543,601 & 50 & -10.43 & -2.81 & 12.02 \\
\hline EkombeMofako & Pump well & 508,604 & 496,923 & 55 & -17.44 & -4.05 & 15.3 \\
\hline Mosongesele & Beach & 466,685 & 544,472 & 10 & -4.68 & -2.15 & 12.53 \\
\hline Beach, EkondoTiti & Beach & 500,637 & 509,210 & 21 & 0.09 & -1.19 & 9.65 \\
\hline Moko, Dibonda & River & 488,936 & 536,277 & 6 & -3.43 & -2.1 & 13.33 \\
\hline Mbonge & River & 511,578 & 499,171 & 26 & -16.24 & -3.78 & 13.96 \\
\hline EkombeLiongo & River & 511,552 & 497,985 & 33 & -15.82 & -3.69 & 13.69 \\
\hline River Akwafe & River & 457,448 & 532,620 & 2 & -0.1 & -1.24 & 9.48 \\
\hline Water catchment, Mundemba & Stream & 490,170 & 550,703 & 166 & -11.08 & -3.04 & 13.24 \\
\hline Berenge & Steam & 517,579 & 513,099 & 59 & -8.49 & -2.63 & 12.57 \\
\hline Ekondo Nene & Stream & 495,435 & 518,788 & 25 & -8.61 & -2.93 & 14.84 \\
\hline Manja quarters, Mundemba & Stream & 490,215 & 550,398 & 109 & -10.61 & -2.95 & 12.96 \\
\hline Lobe Estate & Tap water & 508,437 & 508,645 & 67 & -10.95 & -2.98 & 12.89 \\
\hline Mundemba town & Reservoir & 490,242 & 550,613 & 169 & -10.43 & -2.91 & 12.83 \\
\hline
\end{tabular}


Table 2 (continued)

\begin{tabular}{llllllll}
\hline Locality & Water source & Long $(\mathrm{m})$ & Lat $(\mathrm{m})$ & Altitude & $\delta \mathrm{D}(\% \circ)$ & $\delta^{18} \mathrm{O}(\% \circ)$ & $\mathrm{d}-\mathrm{excess}(\% \circ)$ \\
\hline Last Camp, Mundemba & Rain & 482,814 & 544,840 & 13 & 12.59 & 0.1 & 11.83 \\
Mundemba town & Rain & 490,041 & 551,095 & & 2.29 & 0.35 & 13.88 \\
\hline
\end{tabular}

Table 3 Isotope data summary of ground and surface water $(n=52)$

\begin{tabular}{|c|c|c|c|c|c|c|c|c|c|c|}
\hline \multirow[t]{2}{*}{ Source } & \multicolumn{3}{|c|}{$\delta^{18} \mathrm{O}(\% 0)$} & \multicolumn{3}{|l|}{$\delta \mathrm{D}(\% o)$} & \multicolumn{3}{|c|}{ d-excess $(\% o)$} & \multirow[t]{2}{*}{ Alt $(\mathrm{m})$} \\
\hline & Min & $\operatorname{Max}$ & Mean & Min & $\operatorname{Max}$ & Mean & Min & $\operatorname{Max}$ & Mean & \\
\hline Spring $(n=26)$ & -3.59 & -2.28 & -2.94 & -15.45 & -6.16 & -10.81 & 10.2 & 15.34 & 12.77 & 95 \\
\hline Open well $(n=8)$ & -3.8 & -2.64 & -3.22 & -16.99 & -10.23 & -13.61 & 10.39 & 13.59 & 11.99 & 34 \\
\hline Pump well $(n=4)$ & -4.05 & -2.64 & -3.35 & -17.44 & -8.35 & -12.9 & 12.02 & 15.3 & 13.66 & 35 \\
\hline Groundwater $(n=38)$ & -3.81 & -2.52 & -3.17 & -16.63 & -8.25 & -12.44 & 10.87 & 14.74 & 12.81 & 54.67 \\
\hline $\operatorname{Beach}(n=2)$ & -2.15 & -1.19 & -1.67 & -4.68 & 0.09 & -2.3 & 9.65 & 12.53 & 11.09 & 11 \\
\hline River $(n=4)$ & -3.78 & -1.24 & -2.51 & -16.24 & -0.1 & -8.17 & 9.48 & 13.96 & 11.72 & 5 \\
\hline Stream $(n=4)$ & -3.04 & -2.63 & -2.84 & -11.08 & -8.49 & -9.79 & 12.57 & 14.84 & 13.71 & 7 \\
\hline Surface water $(n=10)$ & -2.99 & -1.69 & -2.34 & -10.67 & -2.83 & -6.75 & 10.57 & 13.78 & 12.17 & 7.67 \\
\hline Tap water $(n=1)$ & -2.98 & -2.98 & -2.98 & -10.95 & -10.95 & -10.95 & 12.89 & 12.89 & 12.89 & 67 \\
\hline Reservior $(n=1)$ & -2.91 & -2.91 & -2.91 & -10.43 & -10.43 & -10.43 & 12.83 & 12.83 & 12.83 & 169 \\
\hline Pipe-borne water $(n=2)$ & -2.95 & -2.95 & -2.95 & -10.69 & -10.69 & -10.69 & 12.86 & 12.86 & 12.86 & 118 \\
\hline $\operatorname{Rain}(n=2)$ & 0.1 & 0.35 & 0.23 & 2.29 & 12.59 & 7.44 & 11.83 & 13.88 & 12.86 & 13 \\
\hline All $(n=52)$ & -2.41 & -1.70 & -2.06 & -8.92 & -2.30 & -5.61 & 11.53 & 13.82 & 12.68 & 48.33 \\
\hline
\end{tabular}

Min minimum, Max maximum, Alt altitude above sea level. Bold values represent the average parameter of ground and surface water samples

Fig. 8 Plot of $\delta^{18} \mathrm{O}$ versus $\delta \mathrm{D}$ relationship of rainfall, ground and surface water in the study area

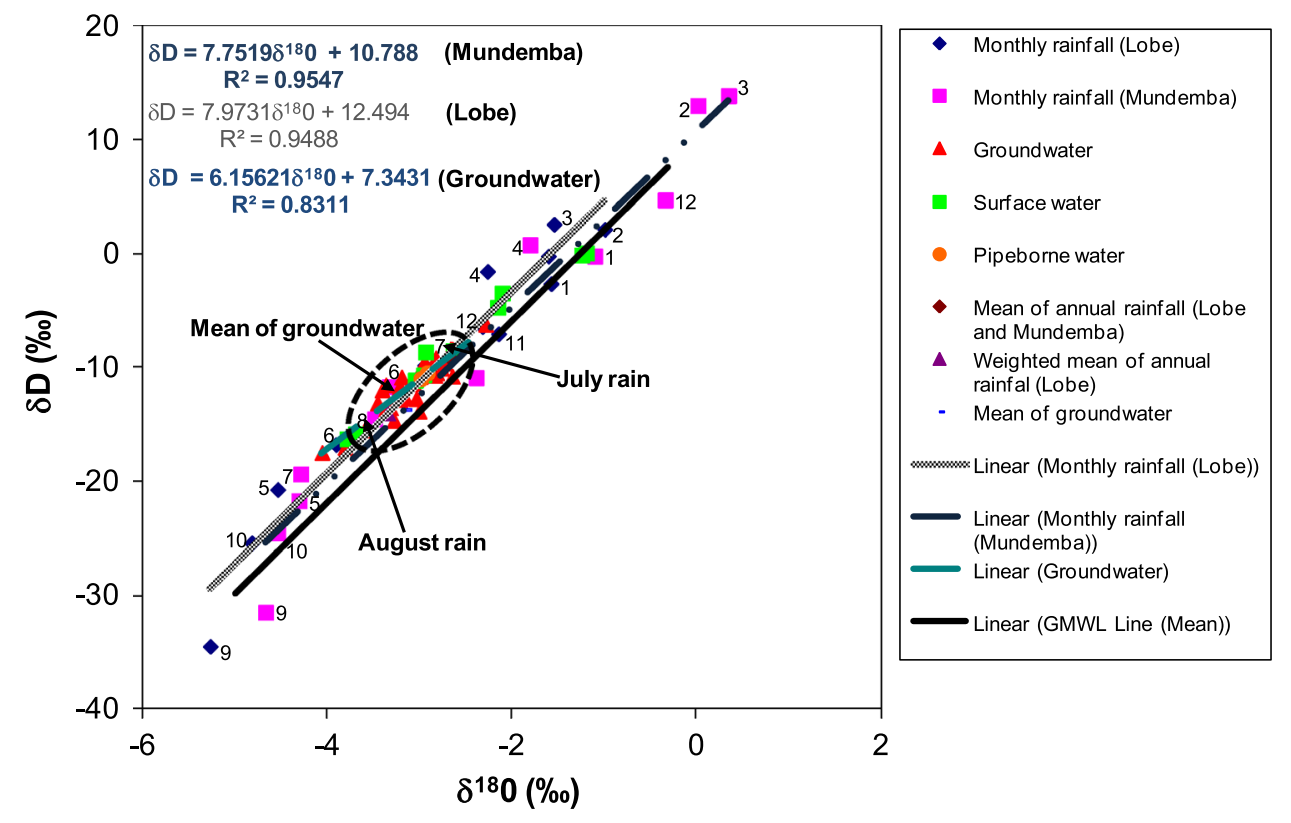

become saturated with June-August precipitation. Isotopic compositions between precipitation and groundwater can reveal the period of groundwater recharge (Mbonu and Travi 1994; Deshpande et al. 2003; Ma et al. 2013) as in the study area. The absence of enriched $\delta^{18} \mathrm{O}$ and $\delta \mathrm{D}$ signatures in the heavy September to October precipitation (Table 1) suggests insignificant recharge during these months. Since the $\delta$-values of the groundwater, streams, and rivers are not significantly affected by evaporation, the dominant recharge period is likely from June to August precipitation and reduced recharge from, November to December. During the low January-April precipitation, evapotranspiration is 
probably greater than precipitation resulting in negligible groundwater recharge. As observed by Mbonu and Travi (1994), the heaviest rains of July-September with the most negative stable isotopes resulted to negligible recharge of groundwater. This selective recharge may explain the relatively low d-intercept of groundwater despite their cluster along the Mundemba meteoric water line (MMWL) and Lobe meteoric water line (LMWL) (Fig. 8). The observed June-August precipitation recharge is different from the reported heavy August precipitation recharge of groundwater farther away in the semi-arid north Cameroon (Fantong 2010).

Under base flow conditions, streams and rivers are integrators of isotopic composition of the recent past precipitation (Gonfiantini et al 1998; Matsubaya 2001; Gat 2010) provided the basin largely consists of surrounding mountains (Gonfiantini et al. 1998). A plot of the stream and river samples on and next to the MMWL and LMWL (Fig. 8) suggests recharge from the surrounding Rumpi Hills. The similar isotopic composition of surface water to the groundwater (Table 2) suggests a hydraulic connectively with the unconfined aquifers and a possible recharge as it flows within the basin.

The beach sample from Mosongesele and a sample from river Moko located at 10 and 6 m.a.s.l. (Fig. 9), respectively, showed some $\delta^{18} \mathrm{O}$ enrichments suggesting that the groundwater which is mostly from spring sources are partly recharged by these surface water bodies. The general cluster of samples on the $\delta^{18} \mathrm{O}$-TDS plot (Fig. 9) suggests a homogenous nature of the shallow aquifer of $<10 \mathrm{~m}$ depth.

Natural variations in stable isotope ratios have been used to identify recharge areas (Payne and Yurtsever 1974). Plotting $\delta^{18} \mathrm{O}$ versus altitude (Fig. 10) indicated recharge at different altitudes. The plot of samples (Fig. 10) showed 3 clusters (groups).

Group A: Comprises of 70\% of the samples (open wells, pump wells, springs, rivers and beach) which occur at low altitude $<54 \mathrm{~m}$ above sea level (Fig. 10).

Group B: $28 \%$ of samples mostly springs $<160$ m.a.s.l.

Group C: $2 \%$ of the spring at Ekwe (555 m. a.s.l.).

The different groups indicate recharge at different altitudes (From A-C). Group A is the most enriched in $\delta^{18} \mathrm{O}$. The $\delta^{18} \mathrm{O}$ value of precipitation in temperate regions characteristically exhibits about a $0.2 \%$ decrease for every $100 \mathrm{~m}$ elevation gain. This variation reflects the temperature dependence of isotopic fractionation during the condensation of water vapour (Dansgaard 1964). Therefore, they are likely to have short flow paths and short residence times in the aquifer. Using the d-excess value to determine the source of moisture indicates that $96 \%$ of the ground and surface water samples had d-excess values $>10 \%$ with an average of $12.68 \%$ (Tables 2, 3). This indicates that besides the Atlantic moisture, recharge is derived partly from recycled water and direct infiltration of precipitation (negligible evaporation) (Dansgaard 1964). A similar inference from high d-excess in groundwater has been made elsewhere (Kebede and Tavi 2012).

Based on the results, a theoretical model of the groundwater regime in Ndian is proposed (Fig. 11). From the model, vapour from the Atlantic Ocean and recycled moisture will condense to precipitation which rapidly recharges the groundwater through preferential base flow. The high-altitude localized recharge contributes $30 \%$ of the groundwater, while the abundant local precipitation at low altitude provides significant recharge (70\%) to the aquifers (Fig. 11). The groundwater sources
Fig. 9 Plot of $\delta^{18} \mathrm{O}$ and total dissolve solid (TDS) in ground and surface water sources

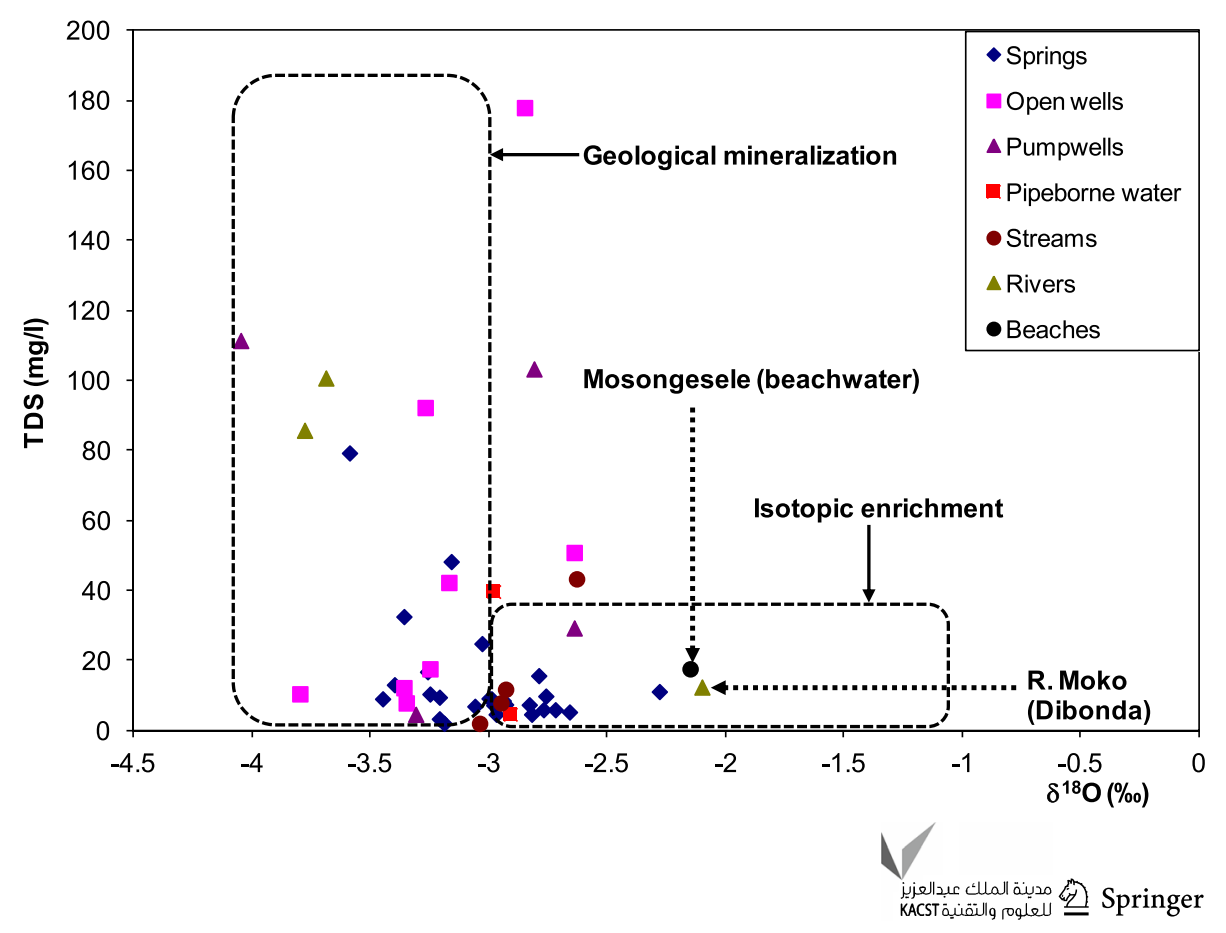


Fig. 10 Plot of $\delta^{18} \mathrm{O}$ in ground and surface water as a function of altitude

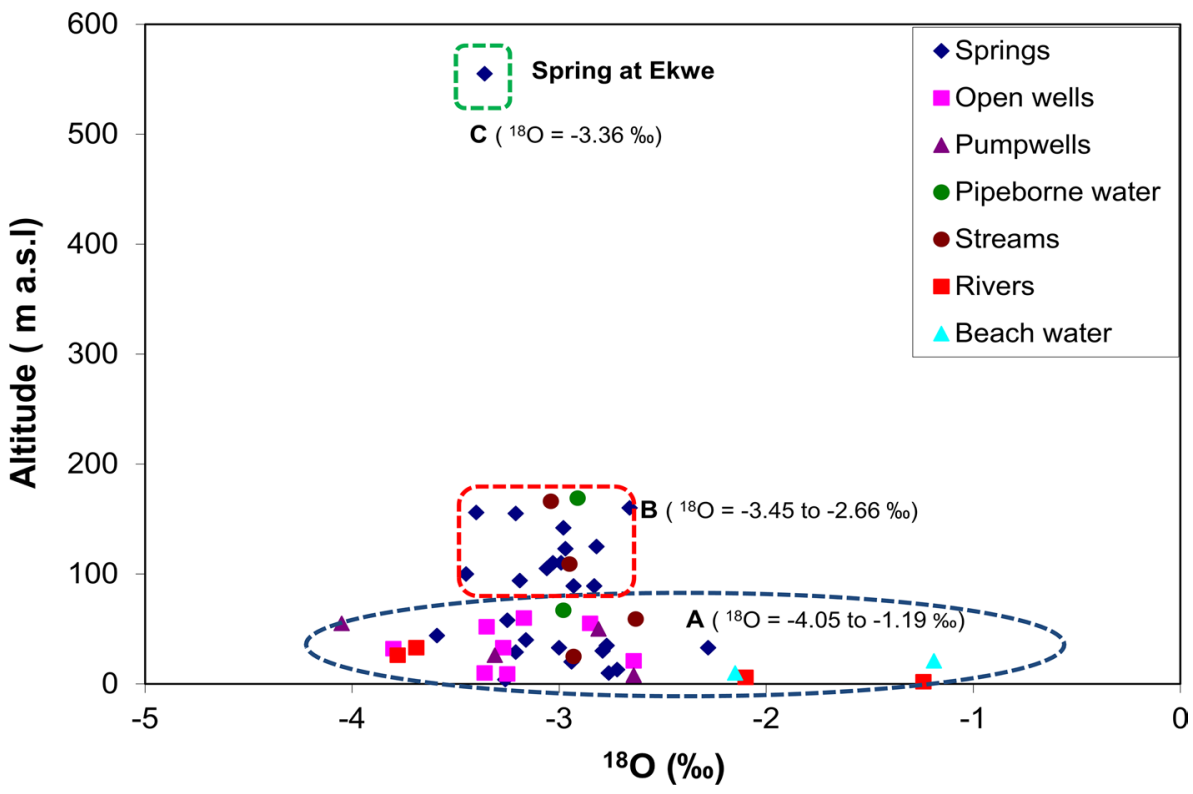

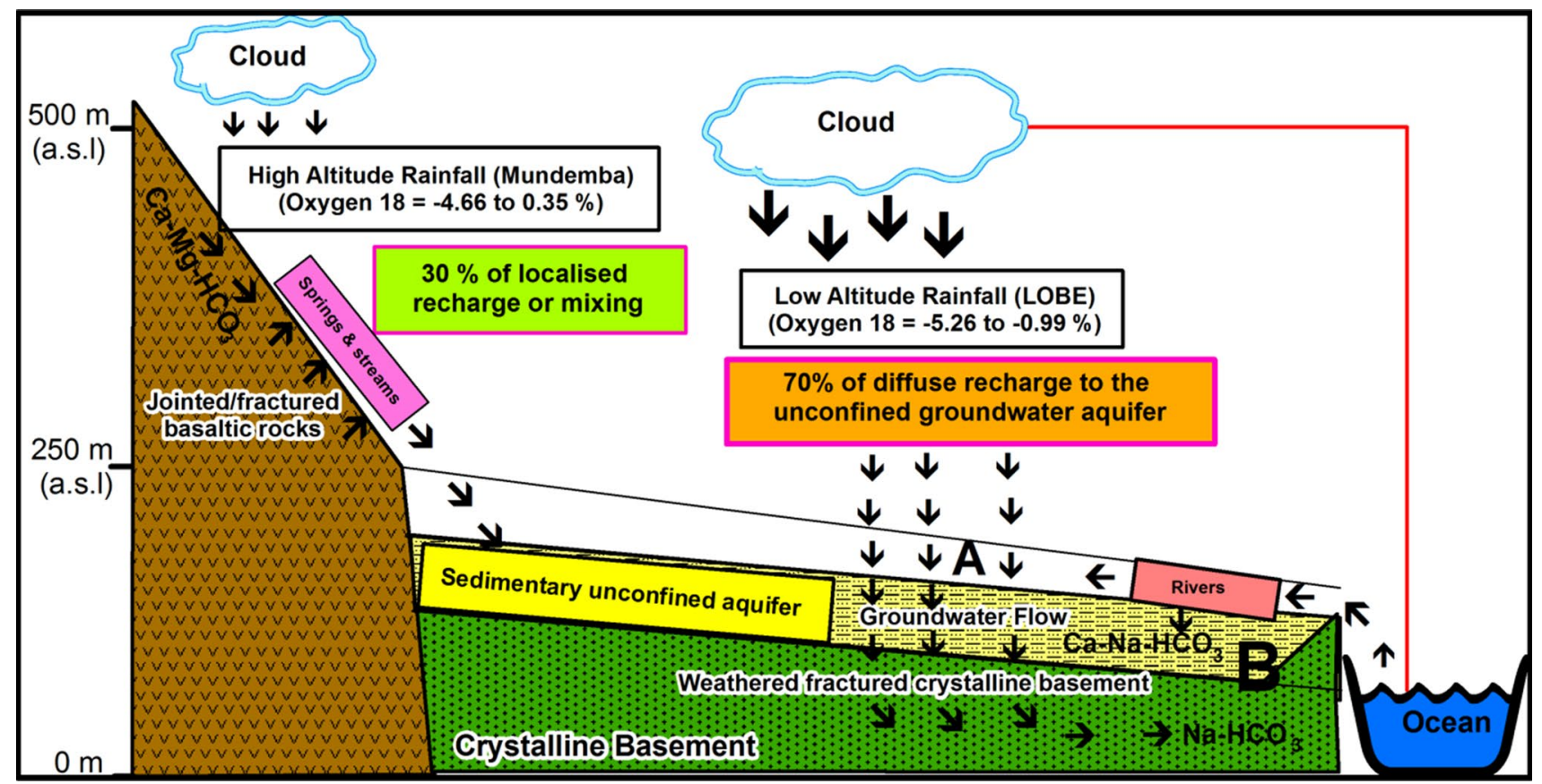

Fig. 11 Conceptual model of the water regime in Rio del Rey Basin. A (vadose zone) and B (saturated zone)

at the high altitude recharge are depleted in $\delta^{18} \mathrm{O}$, while the groundwater sources at low altitude are enriched in $\delta^{18} \mathrm{O}$ (Fig. 11). The hydrochemical facies $\left(\mathrm{Ca}-\mathrm{mg}-\mathrm{HCO}_{3}\right)$ (Fig. 11) signifies shallow fresh groundwater in volcanic and sedimentary aquifers due to incongruent silicate dissolution and $\mathrm{Na}-\mathrm{HCO}_{3}$ facies, deeper fresh groundwater influenced by ion exchange in sediments and metamorphic rocks (Wotany et al. 2013).

\section{Conclusions}

The isotope data for the rainfall samples indicated high values of $\delta^{18} \mathrm{O}$ and $\delta \mathrm{D}$ isotopes recorded during the dry season (November and March) and the least value in September. The relationship between $\delta \mathrm{D}$ and $\delta^{18} \mathrm{O}$ defined the Lobe meteoric water line as $\delta \mathrm{D}=7.97 \delta^{18} \mathrm{O}+12.48$ 
and Mundemba water line as: $\delta \mathrm{D}=7.75 \delta^{18} \mathrm{O}+10.79$. The similarity of their slopes to the global meteoric water line suggests the isotopic composition of rains has not been affected much by evaporation.

The ranges in deuterium-excess of precipitation from 5.8 to $16.56 \%$ o suggest the source of vapour is from Atlantic Ocean.

The groundwater isotope values plot close to and along the GMWL showing that its isotopic composition is of meteoric origin under rapid recharge conditions. The isotopic similarity between groundwater and June-August rains suggests a major recharge during this period. Taking into account the total amount of rainfall in the study area from January to May and November to December which is $2143 \mathrm{~mm} \mathrm{(26 \% )} \mathrm{of} \mathrm{the}$ total rainfall $(8259 \mathrm{~mm})$, and the June to October heavy rains which is $6116 \mathrm{~mm} \mathrm{(74 \% )}$ of the total rainfall, and based on the d-excess and $\delta$-values, one can suggest that $74 \%$ of rainfall comes from the Atlantic Ocean, and $26 \%$ of vapour originates from recycled inland moisture.

The observed seasonal variation in isotopic composition of precipitation in the study area is probably as a result of: (1) Moisture from the Atlantic Ocean, (2) rainfall amounts effects (3) recycled moisture given the 32-61 km distance south west from the Atlantic Ocean (Gulf of Guinea), (4) movement of air masses. The groundwater sources at the high altitude recharge are depleted in $\delta^{18} \mathrm{O}$, while the groundwater sources at low altitude are enriched in $\delta^{18} \mathrm{O}$. The high altitude localized recharge contributes $30 \%$ of the groundwater, while the abundant local precipitation at low altitude provides major recharge (70\%) to the shallow unconfined aquifers.

Acknowledgements We thank the staff of the Lobe and Ndian Estate Research Centre for the monthly field collection of rain samples, weather data and members of the Takeshi Ohba Laboratory, Tokai University, Japan for the stable isotope analysis. The paper was greatly improved by review comments from two anonymous reviewers.

Funding This work was carried out under a $\mathrm{PhD}$ research programme of the University of Buea - Cameroon, without a grant.

\section{Declarations}

Conflict of interest The authors declare that they have no conflict of interest.

Ethical approval This article does not contain any studies involving human participants performed by any of the authors.

Informed consent Informed consent was obtained from all individual participants included in the study.

Open Access This article is licensed under a Creative Commons Attribution 4.0 International License, which permits use, sharing, adaptation, distribution and reproduction in any medium or format, as long as you give appropriate credit to the original author(s) and the source, provide a link to the Creative Commons licence, and indicate if changes were made. The images or other third party material in this article are included in the article's Creative Commons licence, unless indicated otherwise in a credit line to the material. If material is not included in the article's Creative Commons licence and your intended use is not permitted by statutory regulation or exceeds the permitted use, you will need to obtain permission directly from the copyright holder. To view a copy of this licence, visit http://creativecommons.org/licenses/by/4.0/.

\section{References}

Aggarwal P (2002) Isotope hydrology at the International Atomic Energy Agency. Hydrol Process 16(11):2257-2259. https://doi. org/10.1002/hyp.5043

Brand WA, Geilmann H, Crosson ER, Rella CW (2009) Cavity ringdown spectroscopy versus high-temperature conversion isotope ratio mass spectrometry: a case study on $\delta 2 \mathrm{H}$ and $\delta 18 \mathrm{O}$ of pure water samples and alcohol/water mixtures. Rapid Commun Mass Spectrom 23:1879-1884

Clark I, Fritz P (1997) Environmental Isotopes in hydrogeology. Lewis Publishers, Boca Raton

Craig H (1961) Isotopic variations in meteoric waters. Science 133:1702-1703

Dansgaard W (1964) Stable isotope in precipitation. Tellus 16:436-468

Deshpande RD, Bhattacharya SK, Jani RA, Gupta SK (2003) Distribution of oxygen and hydrogen isotopes in shallow groundwaters from southern India: influence of a dual monsoon system. J Hydrol 271:226-239

Dumort JC (1968) Carte Géologique de reconnaissance avec notice explicative feuile Douala-Ouest. Bureau des Recherché Géologique et minière, Yaoundé, 131

Edet AE (2009) Characterization of groundwater contamination using factor analysis in the Niger Delta (Nigeria). J Hydrol Eng 14(11):1255-1261

Etia PM (1980) Climate. In: Atlas of the United republic of Cameroon. Groupe J.A. -51, Avenue des Ternes - 75017 Paris, pp 1-72 or to be specific. pp 16-19

Fantong WY (2010) Hydrogeochemical and environmental isotopic study of groundwater in Mayo Tsanaga river basin, northern Cameroon: implication for public groundwater supply management. $\mathrm{Ph}$.D. thesis, University of Toyama, p 211

Feng Q, Wei L, Su YH, Zhang YW, Si JH (2005) Distribution and evolution of water chemistry in Heihe River Basin. Environ Geol 45:947-956

Fontes JC (1980) Environmental isotopes in groundwater hydrology. In: Fritz P, Fontes JC (eds) Handbok of environmental isotope geochemistry, vol 1. The terrestrial environment. Elsevier, Amsterdam, pp 75-134

Fontes JC, Olivry JC (1977) Composition isotopique des précipitations de la region du Mont Cameroun. ONAREST. Inst. de Recherches sur les Techniques, l'Industrie et le Soussol. p 28

Gabche CE, Smith VS (2002) Water, salt and nutrients budgets of two estuaries in the coastal zone of Cameroon. W Afr J Appl Ecol 3:69-89

Gat JR (2010) Isotope hydrology: a study of the water cycle. Series on environmental science and management, vol 6. Imperial College Press, London, p 189

Gat JR, Bowser CJ, Kendall C (1994) The contribution of evaporation from the Great Lakes to the continental atmosphere: estimate based on stable isotope data. Geophys Res Lett 21:557-560

Gibson J, Edwards T, Bursey G (1993) Estimating evaporation using stable isotopes: Quantitative results and sensitivity analysis for two catchments in northern Canada. Nord Hydrol 24:79-94

Gibson J, Edwards T, Birks S et al (2005) Progress in isotope tracer hydrology in Canada. Hydrol Process 19(1):303-327. https://doi. org/10.1002/hyp.5766 
Gonfiantini R, Frohlich K, Araguas-Araguas L, Rozanski K (1998) Isotopes in groundwater hydrology. In: Kendall C, McDonell JJ (eds) Isotope tracers in catchment hydrology. Elsevier, Amsterdam, pp 203-246

Gonfiantini R, Roche MA, Olivry JC, Fontes JC, Zuppi GM (2001) The altitude effecton the isotopic composition of tropical rains. Chem Geol 181:147-167

Goni IB (2006) Tracing stable isotope values from meteoric water to groundwater in the southwestern part of the Chad basin. Hydrogeol J 14:742-752

IAEA (International Atomic Energy Agency) (1980) Arid zone hydrology: investigations with isotope techniques. In: Proceedings of an advisory group meeting. Vienna: IAEA

IAEA (1992) Statistical treatment of data on environmental isotopes in precipitation. Technical Report Series No. 331, IAEA, Vienna, p 720

IAEA (2001) Environmental isotopes in the hydrological cycle, principles and applications, volume III: surface water. In: W. Mook (ed) International hydrological programme, Technical Documents in Hydrology 39. IAEA, Vienna

Ingraham NL (1998) Isotopic variations in precipitation. In: Kendall C, McDonell (eds) Isotope tracers in catchment hydrology. Elsevier, Amsterdam, pp 87-118

Jouzel J, Froehkich K, Schotterer U (1997) Deuterium and oxygen-18 in present-day precipitation: data and modeling. HydrologicalScience 42(5):747-763. https://doi.org/10.1080/02626669709492070

Kebede S, Tavi Y (2012) Origin of the $\delta^{18} \mathrm{O}$ and $\delta^{2} \mathrm{H}$ composition of meteoric waters in Ethiopia. Quartern Int 257:4-12

Kendall C, Coplen T (2001) Distribution of oxygen-18 and deuterium in river waters across the United States. Hydrol Process 15(7):1363-1393. https://doi.org/10.1002/hyp.217

Letouzey R (1985) Notice de la Carte Phytogéographique du Cameroun. Encyclopédie Biologique 69, Editions Paul Lechevalier, Paris

Liu F, Williams M, Caine N (2004) Sources waters and flow paths in an alpine catchment, Colorado Front Range, USA. Water Resour Res 40:W09401. https://doi.org/10.1029/2004WR003076

Loehnert EP (1988) Major chemical and isotope variations in surface and subsurface waters of West Africa. J Afr Earth Sci 7:579-588

Ma J, He J, Qi S, Zhu G, Zhao W, Edmunds WM, Zhao Y (2013) Groundwater recharge and evolution in the Dunhuang Basin, northwestern China. Appl Geochem 28:19-31

Mafany GT, Fantong WY, Nkeng GE (2006) Quality of groundwater in Cameroon and its vulnerability to pollution. In: Xu Y, Brent U (eds) Groundwater pollution in Africa. Taylor and Francis (Balkema), Netherlands, pp 47-55

Matsubaya O (2001) General features on the hydrogen and oxygen isotopic ratios of natural water. In: Yoshida N (ed) Hydrogen and oxygen isotopes in hydrology. The textbook for the Eleventh IHP Training Course in 2001, pp 11-42

Mbonu M, Travi Y (1994) Labelling of precipitation by stable isotopes $(18 \mathrm{O}, 2 \mathrm{H})$ over the Jos Plateau and the surrounding plains, northcentral Nigeria. J Afr Earth Sci 19:91-98

Ndian (2012) Meteorology data. Lobe-Ndian PAMOL Research Centre Njitchoua R, Sigha-Nkamdjou L, Dever L, Marlin C, Sighomnou D, Nia P (1999) Variations of the stable isotopic compositions of rainfall events from the Cameroon rain forest, central Africa. J Hydrol 223:17-26

Njoh OA, Petters SW (2008) Upper cretaceous foraminifera of the Rio-Del-Rey Basin, South-West Cameroon. Afr Geosci Rev 01 \& 02:51-63

Obenesaw OO, Njung T, Fongwei G (1997) Geographical reconnaissance for and undergroundwater source at Pamol Estate Lobe, EkondoTiti, Cameroon

Okereke CS, Esu EO, Edet AE (1998) Determination of potential groundwater sites using geological and geophysical techniques in the Cross-River State, southern Nigeria. J Afr Earth Sci 27(1):149-163

Payne BR, Yurtsever Y (1974) Environmental isotopes as a hydrogeological tool in Nicaragua. In: Isotope techniques in groundwater hydrology: proceedings of a symposium, vol 1. IAEA, Vienna

Regnoult JM (1986) Synthesegeologique du Cameroon. SODEXIC, Yaounde

Rozanski K, AraAraguás-Araguás L, Gonfiantini R (1993) Isotope patterns in modern global precipitation. In: Swart PK, Lohmann $\mathrm{KC}$, McKenzie J, Savin S (eds) Climate change in continental isotopic records. Geophy. Mongr. Ser., vol 78, AGU, Washington, DC. pp 1-36

Salati E, Dall'Olio A, Gat J, Matsui E (1979) Recycling of water in the Amazon basin: an isotope study. Water Resour Res 15:1250-1258

Takem EG, Chandrasekharam D, Ayonghe SN, Thambidurai P (2010) Pollution characteristics of alluvial groundwater from springs and bore wells in semi-urban informal settlement of Douala, Cameroon, western Africa. Environ Earth Sci 61:287-298

Taupin JD, Coudrain-Ribstein A, Gallaire R, Zuppi GM, Filly A (2000) Rainfall characteristics $(\delta 18 \mathrm{O}, \delta 2 \mathrm{H}, \Delta \mathrm{T}$ and $\Delta \mathrm{Hr})$ in western Africa: regional scale and influence of irrigated areas. J Geophys Res 105:11911-11924

Tening AS, Asongwe GA, Chuyong GB, Fonge BA, Mvondo-Ze AD (2014) Heavy metal status in the Rio del Rey mangroves of Cameroon. Int J Current Microbiol Appl Sci 3(12):701-717

Thomas D (1995) Botanical survey of the Rumpi Hills Ali. Report to the Korup Project

Thomas D (1997) Botanical survey of the Ejagham Forest Reserve, Cameroon. Report to the Korup Project

UNESCO - ISARM (2011) Aquifères Transfrontaliers au Cameroun. 2eme atelier en Afrique de l'Ouest et extension à l'Afrique Centrale, Douala, Cameroun

Wirmvem MJ, Ohba T, Fantong WY, Ayonghe SN, Suila JY, Asaah ANE, Asai K, Tanyileke G, Hell JV (2014) Monthly $\delta 180$, סD and $\mathrm{Cl}$ - characteristics of in, Northwest Cameroon: Baseline data. Quatern Int 338(2014):35-41

Wotany ER, Ayonghe SN, Fantong WY, Wirmvem MJ, Ohba T (2013) Hydrogeochemical and anthropogenic influence on the quality of water sources in the Rio del Rey Basin, South Western Cameroon, Gulf of Guinea. Afr J Environ Sci Technol 7:1053-1069

Wotany ER, Ayonghe SN, Fantong WF, Wirmvem JM, Wantim MN (2014) Hydrochemical characteristics of groundwater in sedimentary, metamorphic and volcanic aquifers in Ndian Division, South West Region, Cameroon. J Cameroon Acad Sci 11(2 \& 3): $157-170$

Wu J, Ding Y, Ye B, Yang Q, Hou D, Xue L (2012) Stable isotopes in precipitation in Xilin River Basin, northern China and their implications. Chin Geogr Sci 22(5):531-540. https://doi.org/10. 1007/s11769-012-0543-z

Zhou S, Nakawo M, Sakai A et al (2007) Water isotope variations in the snow pack and summer precipitation at July 1 Glacier, Qilian Mountains in northwest China. Chin Sci Bull 52(21):2963-2972. https://doi.org/10.1007/s11434-007-0401-z

Zimmermann L (2000) A comparative study of growth and mortality of tress in ceasalp dominated low town African rainforest at Korup, Cameroon

Publisher's Note Springer Nature remains neutral with regard to jurisdictional claims in published maps and institutional affiliations 